\title{
The Federal Constitutional Court Rules for a Bright Future of Constitutional Pluralism
}

\author{
Matej Avbelj*(i) \\ (Received 22 February 2020; accepted 24 February 2020)
}

\begin{abstract}
The ruling of the German Federal Constitutional Court in the Right to be forgotten II case is an example of constitutional pluralism in action. It demonstrates how a pluralist-minded court can elevate itself from and above the constitutional confines of its own legal order. By integrating the material standards of another legal order in its own review of constitutionality a national constitutional court contributes directly to the strengthening of the fundamental rights of individuals against the national authorities within the overall system of European legal order.
\end{abstract}

Keywords: German Federal Constitutional Court; Constitutional Pluralism; EU Law; Human Rights; Right to be Forgotten

\section{A. Introduction}

Just before the end of 2019 the German Federal Constitutional Court (hereinafter the Court or FCC) delivered a ruling ${ }^{1}$ with a resounding practical and theoretical echo for the European constitutional law. The Court was seized by an individual's constitutional complaint, inter alia, alleging the violation of the right to be forgotten as part of a right to free development of her personality as protected under the German Grundgesetz. However, the FCC, noting that the invoked field of human rights protection has been fully harmonized under EU law, restated her claim, divorced it from the German constitutional standards of human rights protection and rather subsumed it under Articles 7 and 8 of the EU Charter of Fundamental Rights. In so doing, the Court has arrived at three profoundly novel results. First, it has turned EU law in a legal basis for a constitutional complaint. Second, it has thus made EU law into a benchmark of constitutionality in Germany. Third, it has reconceived itself as an EU law court, filling the gap in the overall system of judicial protection of individuals under EU law. This contribution argues that with this ruling the FCC has validated the theory of constitutional pluralism and put it in its best possible light.

\section{B. The Past and Present of Constitutional Pluralism}

Constitutional pluralism used to be very unpopular. It was perceived as an attack on the essence of EU distinctive system of supranationality, whose guarantee was uniform EU law. The latter was built around the constitutional principles of autonomy, direct effect, supremacy, loyalty,

\footnotetext{
${ }^{*}$ Faculty of Government and European Studies, European Law, Kranj, Slovenia.

${ }^{1}$ BVerfG, Nov. 6, 2019, docket number 1 BvR 276/17 - Right to be forgotten II.
} 
preemption and human rights protection. ${ }^{2}$ These principles were to be followed entirely and unconditionally. Any deviation, even if justified, was considered as incompatible with the prevailing constitutional orthodoxy of an ever closer Union. The national constitutional courts, which did very early on accept the autonomy of EU law, however, refused to buy into the unconditional supremacy of EU law. After all, they reasoned, the establishment of autonomy of EU law does not deprive national legal orders of their autonomy. Hence, not only did national constitutional courts insist that there are certain legal limits to the integration process (contro limiti), ${ }^{3}$ the EU's claim to its own legal autonomy required also the latter to live up to the requirements of human rights protection, democracy, rule of law, as well as division of competences. ${ }^{4}$

The Constitutional Courts of Italy and of Germany, in particular, were in the driver's seat of this jurisprudence, which was for a long time heavily criticized by dominant currents of EU scholarly community. Until a single, but very theoretically influential voice, belonging to Neil MacCormick, uttered that after all that constitutional jurisprudence did have a sound basis in legal theory. ${ }^{5}$ This has led to the birth and flourishing of the theory of constitutional pluralism - even a movement, ${ }^{6}$ which has, however, continued to split opinions between its supporters and others who have blamed it for almost everything that has not been right in the Union. ${ }^{7}$ I have, on the other hand, always believed that constitutional pluralism understood as principled legal pluralism provides the best descriptive, explanatory and normative account of European integration. ${ }^{8}$

Accordingly, I have conceived of the EU as a plurality of a supranational and 28 national legal orders, which are drawn together into a pluralist common whole through a nexus of relational principles that enable the individual legal orders to function both autonomously as well as part of a coherent common whole. ${ }^{9}$ These legal orders, while existing as distinct epistemic sites ${ }^{10}$ behind their fundamental boundaries, ${ }^{11}$ have and should have developed an ethos of a dialectically open-self, which enables them to practice a double pluralist commitment: to the autonomy, being constitutive of plurality, and to pluralism, being a source of the shared common whole. ${ }^{12}$ I have argued that such a theoretical account comes with several advantages. It is an inclusive theory that tries to integrate the claims of all legal orders involved, maximizing their interests within the perspective of a common pluralist whole. ${ }^{13}$ It presents a via media between the two extremes of particularist exceptionalism and identity-emptying universalism, which preserves for every participating legal order the right to remain different, but simultaneously preventing them to be conceited, isolationist and autopoietic. As such pluralism is a source of productive contestation, ${ }^{14}$ like a system of check and balances, that drives the participating legal orders not just towards mutual

\footnotetext{
${ }^{2}$ Joseph H.H. Weiler, Federalism without Constitutionalism: Europe's Sonderweg, in The Federal Vision, LEGITIMACY AND LeVels of Governance in the United States ANd the European Union 54 (Kalypso Nicolaidis ed., 2001).

${ }^{3}$ Marta Cartabia, The Italian Constitutional Court and the Relationship Between the Italian Legal System and the European Community, 12 Mich. J. INT'L L. 173 (1990).

${ }^{4}$ BVerfG, Oct. 12, 1993, docket number 2 BvR 2134, 2159/92, 89 BVERFGE 155; see also the Lisbon ruling of the German Constitutional Court, BVerfG, June 30, 2009, docket number 2 BvE 2/08; the Constitutional Court of the Czech Republic, Mar. 8, 2006, docket number Pl US 50/04; the Polish Constitutional Court, May 11, 2005, docket number K 18/04; Spanish Constitutional Court, Dec. 13, 2004, Case No. DTC 1/2004, etc.

${ }^{5}$ Neil MacCormick, The Maastricht Urteil: Sovereignty Now, 1 EUR. L.J. 259, 265 (1995).

${ }^{6}$ Julio Baquero Cruz, The Legacy of Maastricht Urteil and the Pluralist Movement, 14 EUR. L.J. 389 (2008).

${ }^{7}$ See, most recently, R. Daniel Kelemen, The Dangers of Constitutional Pluralism, in Research HandBook ON LEgaL Pluralism and EU Law 392 (Garreth Davies \& Matej Avbelj eds, 2018).

${ }^{8}$ Matej Avbelj, The European Union under Transnational law: A Pluralist Appraisal (2018), Ch 2.

${ }^{9}$ Matej Avbelj, Supremacy or Primacy of EU Law - (Why) Does it Matter? 17 EUR. L.J. 744 (2011).

${ }^{10}$ Neil Walker, The Idea of Constitutional Pluralism, 65 MODERN L.R. 317 (2002).

${ }^{11}$ Joseph H.H. Weiler, Fundamental Rights and Fundamental Boundaries: On Standards and Values in the Protection of Human Rights, in The European Union and Human Rights 51, 52 (Nanette A. Neuwahl \& Alan Rosas eds, 1995).

${ }^{12}$ Avbelj, supra note 8, Ch 2.

${ }^{13} I d$., at 38 .

${ }^{14}$ Nico Krisch, Beyond Constitutionalism (2010).
} 
adaptation, but also mutual improvement. In this way, principled legal pluralism provides a learning platform, which is simultaneously a measure of legitimacy of the participating legal orders that depends on the quality and intensity of their engagement. ${ }^{15}$

\section{Constitutional Pluralism - Not Yet Forgotten}

All of the above described theoretical elements of constitutional pluralism can be identified in the landmark ruling of the FCC that this contribution is dedicated to. The FCC's reasoning clearly proceeds from the premise of a plurality of legal orders. There is a German and an EU legal order, each with its own formal and substantive properties, of which fundamental rights constitute an important part. Hence, in the pluralist vein "the EU fundamental rights and domestic fundamental rights must be regarded as distinct regimes." ${ }^{16}$ Their distinctiveness does not derive just from the formal positivist sense, e.g. because they belong to different legal orders. No, the difference between the two regimes is also social and therefore epistemic. In the words of FCC:

At present, it cannot be assumed that the respective fundamental rights standards in the Member States are congruent beyond the common fundament that is the European Convention on Human Rights. Rather, domestic fundamental rights frameworks reflect cultural differences between the Member States resulting from various factors, as well as country-specific historical experiences. It can also not be assumed that the fundamental rights protection under the Charter of Fundamental Rights specifically matches the fundamental rights protection under the German Basic Law. ${ }^{17}$

In short, the EU legal order and the German legal order are two different epistemic sites belonging to two different polities, and these differences translate also in the different understandings as well standards of protection even of fundamental rights. It goes without saying that a described plurality of legal orders with differing material standards of human rights protection can provoke conflicts between legal orders. The centrality of conflict is also something that constitutional pluralism, both in its affirmative as well as critical account, has been preoccupied with, although unnecessarily and unjustly so. As the case at hand demonstrates, the strength of constitutional pluralism might be precisely in resolving or at least avoiding the conflicts between legal orders. There are namely various strategies and bridging mechanisms available in the theoretical repository of constitutional pluralism.

The first is to clearly delineate competences. This is precisely what FCC does by distinguishing between two types of fundamental rights related cases. The first are those in which the national legislation, which implements EU human rights standards, preserves the discretion to deviate from the common EU standards. The second are those in which the national legislation has been fully harmonized, e.g. unified by EU standards. In the first type of cases, in the scope of discretion preserved by it, national legislation implementing EU law continues to be subject to the domestic constitutional review. This is part of an already well established jurisprudence in Germany and beyond. However, when the national legislation has been fully harmonized and hence essentially materially co-opted under EU law, the review can no longer be exercised against national law, but it must be - due to the autonomy of EU law and the national respect for it - reviewed against the standards of EU law.

This is fairly undisputed and not really novel. What is groundbreaking in the present case, is that the FCC declared itself competent to review the domestic application of unified EU law in the

\footnotetext{
${ }^{15}$ Nicole Roughan, Authorities: Conflicts, Co-Operation and Transnational Legal Theory (2013).

${ }^{16}$ BVerfG, Press Release No. 84/2019, Nov. 27, 2019, https://www.bundesverfassungsgericht.de/SharedDocs/Pressemitteilungen/ EN/2019/bvg19-084.html, para. 2b.

${ }^{17} I d$. at $2 \mathrm{a}$.
} 
domestic constitutional procedure with a constitutional complaint for its compliance with EU law standards of human rights protection. None of that would follow from the monistic national constitutional understanding. In accordance with it, national constitutional courts review national legal acts for compliance with the national constitution. The correct application of EU law, including in the field of human rights, used to be a task exclusively for the ordinary courts in their judicial cooperation with CJEU. The national constitutional courts, as the Spanish Constitutional Court explicitly put it, considered this matter as being of infra-constitutional character and hence none of their business. ${ }^{18}$

Not anymore. The FCC, fully endorsing the pluralist position, directly applies EU fundamental rights law as a standard for constitutional review in Germany. It does so following the normative prescriptions of a dialectically open self in order "to discharge its responsibility with respect to European integration," ${ }^{19}$ closing the gap in protection of the individuals under EU law as they cannot turn directly to CJEU when the national authorities (potentially) violate their rights under EU law. However, the FCC's pluralist commitment does not end here. Since the FCC applies fundamental rights as protected in another, eg EU legal order, doubts could emerge as to their correct interpretation and even validity. To respect the autonomy of EU law and the prerequisites for its uniform interpretation across the EU, the FCC also made clear in this case that it would in the circumstances lacking guidelines of correct interpretation seek this at the CJEU by way of a preliminary ruling procedure. ${ }^{20}$

\section{Conclusion}

The ruling of the German Federal Constitutional Court in the Right to be forgotten II case is an example of constitutional pluralism in action. It demonstrates how a pluralist-minded court can elevate itself from and above the constitutional confines of its own legal order. By integrating the material standards of another legal order in its own review of constitutionality a national constitutional court contributes directly to the strengthening of the fundamental rights of individuals against the national authorities within the overall system of European legal order.

\footnotetext{
${ }^{18}$ Spanish Constitutional Court, Feb. 14, 1991, docket number 28/1991.

${ }^{19}$ BverfG, supra note 16 , at para. 3 b.

${ }^{20} I d$., at para. 4 .
}

Cite this article: Avbelj M (2020). The Federal Constitutional Court Rules for a Bright Future of Constitutional Pluralism. German Law Journal 21, 27-30. https://doi.org/10.1017/glj.2020.13 